\title{
The Effects of Centella asiatica Extract (CAE) on Methamphetamine-Induced Neurotoxicity via Human Neuroblastoma Cell Line
}

\author{
Nursyamila Shamsuddin ${ }^{1}$, Mohd Shihabuddin Ahmad Noorden ${ }^{1}$, Mohd Ilham Adenan², Nur Hidayah Reshidan² and \\ Mazatulikhma Mat Zain3* \\ ${ }^{1}$ Faculty of Pharmacy, Universiti Teknologi MARA UiTM, Puncak Alam Campus,42300 Bandar Puncak Alam, Selangor, \\ Malaysia \\ ${ }^{2}$ Atta-ur-Rahman Institute of Natural Product Discovery (AuRins), Universiti Teknologi MARA UiTM, Puncak Alam \\ Campus, 42300 Bandar Puncak Alam, Selangor, Malaysia \\ ${ }^{3}$ Institute of Science (IOS), Universiti Teknologi MARA UiTM, 40000 Shah Alam, Selangor, Malaysia
}

\begin{abstract}
Methamphetamine (METH) was reported to caused neurotoxicity and cell death, in vitro. Centella asiatica or 'pegaga' is a native tropical herb with antioxidant and neuroprotective activities. Although the effects of Centella asiatica against oxidative stress and neuronal cell death have been reported in previous studies, however, the potential effects of Centella asiatica against psychostimulant methamphetamine (METH) are limited. Therefore, this study was aimed to evaluate the effects of Centella asiatica extract (CAE) against METH on all-trans retinoic acid, RAdifferentiated human neuroblastoma, $\mathrm{SH}_{-} \mathrm{SY}_{5} \mathrm{Y}$ cells. The RA-differentiated $\mathrm{SH}_{-} \mathrm{SY}_{5} \mathrm{Y}$ cells were used to resemble dopaminergic neuronal-like cells. Cell viability was quantitatively assessed by $3-\left(4,5^{-}\right.$ dimethylthiazol-2-yl)-2 tetrazolium bromide, MTS assay. CAE at varying concentrations from $1 \mathrm{pg} / \mathrm{mL}$ to $1 \mathrm{mg} / \mathrm{mL}$ significantly decreased the viability of the undifferentiated $\mathrm{SH}_{-} \mathrm{SY}_{5} \mathrm{Y}$ cells in a concentrationdependent manner. At $1 \mathrm{mg} / \mathrm{mL}$ of CAE, significantly increased the viability of differentiated $\mathrm{SH}_{-} \mathrm{SY}_{5} \mathrm{Y}$ cells. Meanwhile, CAE at $100 \mu \mathrm{g} / \mathrm{mL}$ and $1 \mathrm{mg} / \mathrm{mL}$ significantly reversed the METH-induced neuronal cell death. The results revealed that promising treatment of CAE on METH-induced neurotoxicity is mediated by its high content of asiaticoside, asiatic acid, madecassoside and madecassic acid. Taken together, this study may suggest CAE as a potential therapeutic treatment for METH-induced neurotoxicity, in vitro.
\end{abstract}

Keywords: Centella asiatica; neuroprotection; methamphetamine; neurotoxicity

\section{INTRODUCTION}

Oxidative stress is referred to as an imbalance production between reactive oxygen species (ROS) and antioxidant which eventually result in cellular damage (McDonnell-Dowling \& Kelly, 2017). Oxidative stress-related drug abuse leads to neurotoxicity and damage to central nervous system (CNS). Methamphetamine (METH) is an amphetamine-type stimulant (ATS) psychoactive drug with devastating neurotoxic effects on CNS (Gailbraith, 2015). Neuronal-cell death induced by METH have been revealed through in vitro and in vivo study (Genc et. al., 2003; Nara et. al., 2010; Ramkissoon \& Wells, 2015).
Pharmacologically, its cationic lipophilic properties make it easily cross the blood-brain barrier (BBB), thus enhances the release of dopamine (DA) from synaptic vesicles and nerve terminals of the CNS. Excessive release of DA is then auto-oxidised into superoxide radicals $\left(\mathrm{O}_{2}{ }^{-}\right)$, hydroxyl radicals $(\mathrm{OH})$ and hydrogen peroxide $\left(\mathrm{H}_{2} \mathrm{O}_{2}\right)$. These releases of radicals lead to the generation of ROS. Excessive ROS eventually cause neuronal cell damage, thus inducing cell death either via apoptosis or necrosis pathway (Wu et al., 2007).

It is well known that the antioxidant defence system acts as free radical scavengers that prevent and minimise 
cellular damage. The use of antioxidant to attenuate the METH-induced neurotoxicity via targeting oxidative stress have been attempted. Unfortunately, till today limited naturalderived medicines have been synthesised to ameliorate neurotoxicity induced by METH. Thus, safe and cost-effective natural-derived medicines with fewer side effects are being proposed as a therapeutic agent to attenuate oxidative stress and neuronal cell death by METH.

Centella asiatica (L.) Urban (Umbelliferae) is a native medicinal herb of tropical Southern Asian countries such as Malaysia, Thailand and Indonesia have been revealed with its potential anti-tumor (Park et al., 2005), neuroprotection (Ramanathan et. al., 2007; Omar et al., 2011), antioxidant (Veerandra Kumar \& Gupta, 2002), anti-hyperlipidemic (Kumari et al., 2016) and wound healing (Sripanidkulchai et al., 2013) anti-inflammatory and anti-bacterial activities (Shen et al., 2019). The plant is rich in bioactive constituents mainly triterpenes such as asiatic acid, asiaticoside, madecassoside and madecassic acid which are major contributors to its pharmacological and antioxidant properties (Zainol et al., 2003). Asiatic acid significantly attenuated the apoptotic SH$\mathrm{SY}_{5} \mathrm{Y}$ cell death and ROS generation following glutamate induction ( $\mathrm{Xu}$ et al., 2012). Asiatic acid also revealed its significant protective effects against cytotoxicity induced by cholesterol on differentiated neuroblastoma $\mathrm{SH}_{-} \mathrm{SY}_{5} \mathrm{Y}$ cells (Ternchoocheep et al., 2017). A study was done by Wang et al. (2019) further reported the protective role of asiatic acid and madecassic acid against metoprolol tartrate-induced enzymatic antioxidant deficit, in vivo male Wistar rat model.

Besides that, asiaticoside has also shown significantly attenuated the 1-methyl-4-phenyl-1,2,3,6-tetrahydropyridine, MPTP-induced neurotoxicity via maintaining redox balance and upregulating Bcl-2/Bax (Xu et al., 2012).

The human neuroblastoma $\mathrm{SH}_{-} \mathrm{SY}_{5} \mathrm{Y}$ cell line was used as the most commonly used and established in vitro model for cytotoxicity and neurotoxicity study. Thus, this present study was conducted to evaluate the effects of CAE treatment against METH-induced neurotoxicity, via in vitro $\mathrm{SH}_{-} \mathrm{SY}_{5} \mathrm{Y}$ cells.

\section{MATERIALS AND METHODS}

\section{A. Materials}

Leaves of Centella asiatica were collected and obtained from Herbagus Trading, Pulau Pinang, Malaysia. The leaves were identified and deposited in the Atta-ur-Rahman Institute for Natural Product Discovery UiTM Puncak Alam, Selangor, Malaysia, Voucher Specimen (no. CA-Ko17). The leaves were washed, oven-dried at $40^{\circ} \mathrm{C}$ and finely ground and stored in a desiccator before use. Approximately $10 \mathrm{~kg}$ of leaves powder was extracted using standard extraction protocol and was performed at the extraction facility (Institute of Bioproducts Development, Universiti Teknologi Malaysia) in 95\% of denatured-ethanol for $8 \mathrm{~h}$ at $60^{\circ} \mathrm{C}$. The crude yield extract was freeze-dried and ground into a dried-powder extract and was designated as Centella asiatica extract (CAE) (Figure 1).

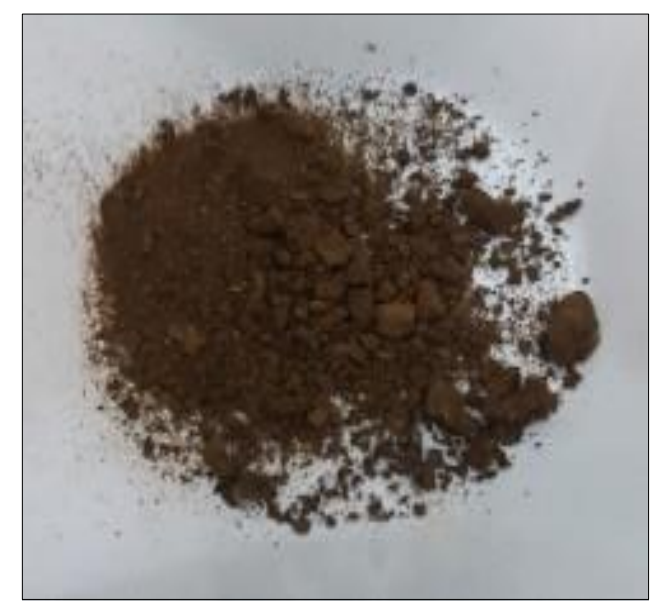

Figure 1. The CAE powder

Methamphetamine (METH) was obtained from Toronto Supply, Canada. Approval for the use of METH was obtained from the Ministry of Health Malaysia (KKM$55 / \mathrm{BPF} / 213 / 005 / 12)$

\section{B. The Human Neuroblastoma, $\mathrm{SH}-\mathrm{SY}_{5} \mathrm{Y}$ Cells}

The human neuroblastoma $\mathrm{SH}_{-} \mathrm{SY}_{5} \mathrm{Y}$ cell (ATCC®) CRL 2266 ${ }^{\mathrm{TM}}$ ) (cat no: 94030304) was purchased from Public Health England Culture Collection (Salisbury, UK) and maintained in 1:1 sterile filtered mixture of Minimum Essential Medium Eagle (MEM) and Nutrient Mixture Ham's F12 supplemented with 1\% gentamicin (Sigma, USA), 
1\% non-essential amino acid (Sigma, USA) and 1\% L-glutamine (Sigma, USA) and 10\% heat-inactivated fetal bovine serum (FBS) (Sigma, USA). Cells were grown in a humidified incubator maintained at $37^{\circ} \mathrm{C}$ with $5 \% \mathrm{CO}_{2}$ until $80-90 \%$ confluent.

The $\mathrm{SH}_{-} \mathrm{SY}_{5} \mathrm{Y}$ cells were harvested once reaching $70-80 \%$ confluency. The old medium was discarded from the flask. A 2mL of 1x phosphate-buffered solution (PBS) was added to wash over the cell monolayer. To detach the cell monolayer, $1 \mathrm{~mL}$ of trypsin-EDTA was added and incubated at room temperature for $1 \mathrm{~min}$. To neutralise the cell pellet, a suspension containing detached cells was collected and transferred into $15 \mathrm{~mL}$ of Falcon tube then centrifuged at 240rpm for $5 \mathrm{~min}$. The supernatant was carefully aspirated and the cell pellet was gently suspended with media. Cell counting was performed using the Cellometer ${ }^{\mathrm{TM}}$ Auto $\mathrm{T} 4$ (Nexcelom, Bioscience). A $20 \mu \mathrm{L}$ of harvested cells was aliquoted into a cell counting chamber. Then, the chamber was inserted into the instrument. The concentration, viability and size were determined automatically.

C. 3-(4,5-dimethylthiazol-2-yl)-2 tetrazolium bromide, MTS Assay

The cell viability was assessed by adding $20 \mu \mathrm{L}$ of CellTiter 96 Aqueous Non-Radioactive Cell Proliferation Assay (Promega, USA). Cell viability was counted by measuring the production of coloured formazan where the percentage of cell viability is directly proportional to the formazan product. Absorbance reading was taken after 4 hours at $490 \mathrm{~nm}$ by using a microplate reader (Glomax Integrated Multidetection System, Promega, USA).

\section{Cytotoxicity Assay}

Undifferentiated $\mathrm{SH}_{-} \mathrm{SY}_{5} \mathrm{Y}$ cells were plated and cultured into the 96-well plates at a concentration of $2 \times 10^{4}$ cells per well. The cells were incubated at $37^{\circ} \mathrm{C}$ with $5 \% \mathrm{CO}_{2}$ for 24 hours. Sample dilutions (METH and CAE) were freshly prepared and stored overnight at $4^{\circ} \mathrm{C}$. After 24 hours, media on each treatment wells were gently aspirated. A $100 \mu \mathrm{L}$ of $1 \mathrm{pg} / \mathrm{mL}, 10 \mathrm{pg} / \mathrm{mL}$, $100 p g / \mathrm{mL}, 1 \mathrm{ng} / \mathrm{mL}, 10 n g m L, 100 n g / \mathrm{mL}, 1 \mu \mathrm{g} / \mathrm{mL}, 10 \mu \mathrm{g} / \mathrm{mL}$, $100 \mu \mathrm{g} / \mathrm{mL}$ and $1 \mathrm{mg} / \mathrm{mL}$ of samples (METH and CAE) were added to each wells. The plates were incubated again for another 1 and 24 hours. Following 24 hours, cell viability was assessed by MTS assay.

\section{E. Neurotoxicity Assay}

Undifferentiated $\mathrm{SH}_{-} \mathrm{SY}_{5} \mathrm{Y}$ cells were cultured into the 96well plates at concentration of $2{\mathrm{x} 10^{4}}^{4}$ cells per well. Cells were incubated at $37^{\circ} \mathrm{C}$ with $5 \% \mathrm{CO}_{2}$ for 24 hours. After 24 hours, media was gently aspirated. For differentiation into neuronal-like cells, all-trans retinoic acid (RA) (Sigma) with a final concentration of $10 \mu \mathrm{M}$ was added to each wells containing undifferentiated $\mathrm{SH}_{-} \mathrm{SY}_{5} \mathrm{Y}$ cells (Forster et al., 2016). The plates were wrapped with aluminium foil and incubated again for the next 5 days. The medium was changed every 2 days and the morphology of neuronal-like cells was observed daily. After 5 days, cells were treated with various concentrations of CAE and METH $(1 \mathrm{pg} / \mathrm{mL}$, $10 \mathrm{pg} / \mathrm{mL}, \quad 100 \mathrm{pg} / \mathrm{mL}, \quad 1 \mathrm{ng} / \mathrm{mL}, \quad 10 n g m L, \quad 100 n g / \mathrm{mL}$, $1 \mu \mathrm{g} / \mathrm{mL}, 10 \mu \mathrm{g} / \mathrm{mL}, 100 \mu \mathrm{g} / \mathrm{mL}$ and $1 \mathrm{mg} / \mathrm{mL}$ ) and incubated at $37^{\circ} \mathrm{C}$ with $5 \% \mathrm{CO}_{2}$ for 24 hours. Following 24 hours of incubation, cell viability was assessed by MTS assay.

\section{F. Neuroprotection Assay}

Differentiated $\mathrm{SH}_{-} \mathrm{SY}_{5} \mathrm{Y}$ cells were pre-exposed with $1 \mathrm{mg} / \mathrm{mL}$ of METH for 24 hours to induce oxidative stress and cytotoxicity. Following 24 hours, cells were posttreated with $1 \mathrm{pg} / \mathrm{mL}, 10 \mathrm{pg} / \mathrm{mL}, 100 \mathrm{pg} / \mathrm{mL}, 1 \mathrm{ng} / \mathrm{mL}$, 10ngmL, $100 n \mathrm{~g} / \mathrm{mL}, 1 \mu \mathrm{g} / \mathrm{mL}, 10 \mu \mathrm{g} / \mathrm{mL}, 100 \mu \mathrm{g} / \mathrm{mL}$ and $1 \mathrm{mg} / \mathrm{mL}$ of $\mathrm{CAE}$ and incubated at $37^{\circ} \mathrm{C}$ with $5 \% \mathrm{CO}_{2}$ for 24 hours. Cell viability was further assessed by MTS assay.

\section{G. Statistical Analysis}

Each experiment was carried out at least in triplicate. The results obtained were analysed by using one way analysis of variance (ANOVA) followed by Tukey's post hoc test using GraphPad ${ }^{\circledR}$ Prism Version 5 (GraphPad Software Inc, USA). The data were expressed as mean \pm SEM, standard error of mean. When the P-value is less than 0.05, significance was considered exist.

\section{RESULTS}

\section{A. Cytotoxicity of METH on Undifferentiated SH- SY5Y Cells}

Cytotoxicity assay was performed to analyse the effects of METH on undifferentiated $\mathrm{SH}_{-} \mathrm{SY}_{5} \mathrm{Y}$ cell survival. An hour incubation of $1 \mathrm{pg} / \mathrm{mL}, 10 \mathrm{pg} / \mathrm{mL}, 100 \mathrm{pg} / \mathrm{mL}, 1 \mathrm{ng} / \mathrm{mL}$, 
10ngmL, $100 n \mathrm{~g} / \mathrm{mL}, \quad 1 \mu \mathrm{g} / \mathrm{mL}, \quad 10 \mu \mathrm{g} / \mathrm{mL}, \quad 100 \mu \mathrm{g} / \mathrm{mL}$ and $1 \mathrm{mg} / \mathrm{mL}$ of METH did not significantly changed the cell viability with $82.08 \pm 1.17 \%, 88.58 \pm 2.09 \%, 87.98 \pm 1.97 \%$,

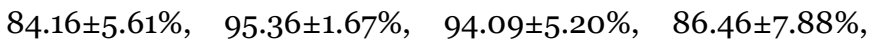
$83.71 \pm 0.88 \%, 83.48 \pm 3.89 \%$ and $90.28 \pm 12.9 \%$ respectively compared to control (untreated cells) (Figure 2A). Meanwhile, 24 hours incubation of $1 \mathrm{pg} / \mathrm{mL}, 10 \mathrm{pg} / \mathrm{mL}, 100 \mathrm{pg} / \mathrm{mL}, 1 \mathrm{ng} / \mathrm{mL}$, 10ngmL, $100 \mathrm{ng} / \mathrm{mL}, 1 \mu \mathrm{g} / \mathrm{mL}, 10 \mu \mathrm{g} / \mathrm{mL}$ and $100 \mu \mathrm{g} / \mathrm{mL}$ of METH did not significantly changed the cell viability with 98.51 $\pm 1.48 \%$ ， 93.08 $\pm 1.26 \%$, 95.96 $\pm 5.18 \% ， 90.10 \pm 12.26 \%$, $95.79 \pm 1.22 \%, 93.98 \pm 5.70 \%, 93.18 \pm 5.29 \%, 96.90 \pm 4.77 \%$ and $86.57 \pm 5.55 \%$ compared to control (Figure 2 ). There was highly significant decreased in cell viability at $1 \mathrm{mg} / \mathrm{mL}$ (more than 50\%) compared to control (Figure 2A).

\section{B. Cytotoxicity of CAE on Undifferentiated $\mathrm{SH}_{-} \mathrm{SY}_{5} \mathrm{Y}$ Cells}

For cytotoxicity of CAE on undifferentiated $\mathrm{SH}_{-} \mathrm{SY}_{5} \mathrm{Y}$ cells, the percentage of cell viability was proportional to MTS assay reduction (Figure $2 \mathrm{~B}$ ). CAE at $1 \mathrm{pg} / \mathrm{mL}$ did not significantly changed the cell viability compared to control. In contrast, CAE at $10 \mathrm{pg} / \mathrm{mL}, 100 \mathrm{pg} / \mathrm{mL}, 1 \mathrm{ng} / \mathrm{mL}, 10 \mathrm{ng} / \mathrm{mL}, 100 \mathrm{ng} / \mathrm{mL}$, $1 \mu \mathrm{g} / \mathrm{mL}, 10 \mu \mathrm{g} / \mathrm{mL}$ and $100 \mu \mathrm{g} / \mathrm{mL}$ significantly decreased the cell viability with $87.18 \pm 1.67 \%, 88.57 \pm 3.39 \%, 86.34 \pm 2.34 \%$, $85.48 \pm 0.78 \%, 83.76 \pm 2.98 \%, 85.62 \pm 2.14 \%, 86.85 \pm 1.27 \%$ and $87.31 \pm 0.38 \%$ respectively compared to control. There was highly significant decreased in cell viability at $1 \mathrm{mg} / \mathrm{mL}$ of CAE with $12.35 \pm 2.91 \%$ compared to control (Figure $2 \mathrm{~B}$ ).

\section{Differentiation of $\mathrm{SH}_{-} \mathrm{SY}_{5} \mathrm{Y}$ Cells into Neuronal-like Cells}

Undifferentiated $\mathrm{SH}_{-} \mathrm{SY}_{5} \mathrm{Y}$ cells were added with the final concentration of $10 \mu \mathrm{M}$ of RA into neuronal-like cells (Figure $3 \mathrm{~A}$ and $3 \mathrm{~B})$.

\section{Neurotoxicity of METH on Differentiated $\mathrm{SH}_{-} \mathrm{SY}_{5} \mathrm{Y}$ Cells}

Neurotoxicity test was performed to determine the neurotoxicity of METH on differentiated $\mathrm{SH}_{-} \mathrm{SY}_{5} \mathrm{Y}$ neuron-like cells, in this study (CAE and METH). There was no significant change in the viability of the differentiated $\mathrm{SH}_{-} \mathrm{SY}_{5} \mathrm{Y}$ cells at $1 \mathrm{pg} / \mathrm{mL}$ following 24 hours incubation. METH-induced neurotoxicity by decreasing the cell survival and viability in a dose-dependent manner. METH at $100 \mathrm{pg} / \mathrm{mL}, 1 \mathrm{ng} / \mathrm{mL}$, $10 \mathrm{ng} / \mathrm{mL}, 100 \mathrm{ng} / \mathrm{mL}$ and $10 \mu \mathrm{g} / \mathrm{mL}$ significantly decreased in cell viability compared to control. Meanwhile, there were highly significant decreases in cell viability at $1 \mu \mathrm{g} / \mathrm{mL}$, $100 \mu \mathrm{g} / \mathrm{mL}$ and $1 \mathrm{mg} / \mathrm{mL}$ of $\mathrm{CAE}$ as compared to control (Figure 4A). METH at $1 \mathrm{mg} / \mathrm{mL}$ was applied for the subsequent study.

\section{E. Neurotoxicity of CAE on Differentiated $\mathrm{SH}_{-} \mathrm{SY}_{5} \mathrm{Y}$ Cells}

Differentiated $\mathrm{SH}_{-} \mathrm{SY}_{5} \mathrm{Y}$ cells were treated with CAE for 24hour incubation. Results showed that there was no significant change in viability of cells at concentration of $1 \mathrm{pg} / \mathrm{mL}, \quad 10 \mathrm{pg} / \mathrm{mL}, \quad 100 \mathrm{pg} / \mathrm{mL}, \quad 1 \mathrm{ng} / \mathrm{mL}, \quad 10 n g / \mathrm{mL}$, $100 \mathrm{gg} / \mathrm{mL}, 1 \mu \mathrm{g} / \mathrm{mL}, 10 \mu \mathrm{g} / \mathrm{mL}, 100 \mu \mathrm{g} / \mathrm{mL}$ of CAE compared to control (Figure 4B). Meanwhile, there was highly significant increase in cell viability at $1 \mathrm{mg} / \mathrm{mL}$ of CAE with $143 \cdot 31 \pm 15.25 \%$ compared to control (Figure 4B).

\section{F. Effects of CAE on METH-induced Neurotoxicity and Cell Death}

To determine the effects of CAE post-treatment against METH-induced neurotoxicity, differentiated $\mathrm{SH}_{5} \mathrm{SY}_{5} \mathrm{Y}$ cells were pre-exposed with $\mathrm{IC}_{50}$ of $\mathrm{METH}(1 \mathrm{mg} / \mathrm{mL})$ to achieve $50 \%$ cell death. Then, cells were post-treated with $1 \mathrm{pg} / \mathrm{mL}$, $10 \mathrm{pg} / \mathrm{mL}, \quad 100 \mathrm{pg} / \mathrm{mL}, \quad 1 \mathrm{ng} / \mathrm{mL}, \quad 10 n g / \mathrm{mL}, \quad 100 n \mathrm{~g} / \mathrm{mL}$, $1 \mu \mathrm{g} / \mathrm{mL}, 10 \mu \mathrm{g} / \mathrm{mL}, 100 \mu \mathrm{g} / \mathrm{mL}$ and $1 \mathrm{mg} / \mathrm{mL}$ of CAE for 24 hours. Results revealed that post-treatment of CAE reverses the toxicity of METH by significantly increased the cell viability through a dose-dependent manner compared to the cells exposed only to METH (Figure $4 \mathrm{C}$ ). At concentrations of $1 \mathrm{pg} / \mathrm{mL}, \quad 10 \mathrm{pg} / \mathrm{mL}, \quad 100 \mathrm{pg} / \mathrm{mL}, \quad 1 \mathrm{ng} / \mathrm{mL}, \quad 10 n g / \mathrm{mL}$, $100 n g / \mathrm{mL}, 1 \mu \mathrm{g} / \mathrm{mL}, 10 \mu \mathrm{g} / \mathrm{mL}$ of $\mathrm{CAE}$, there was no significant change in the cell viability compared to $\mathrm{IC}_{50}$ of METH (Figure 4C). Meanwhile, post-treatment of $100 \mu \mathrm{g} / \mathrm{mL}$ and $1 \mathrm{mg} / \mathrm{mL}$ of CAE significantly increased the cell viability with $78.26 \pm 2.93 \%$ and $93.11 \pm 8.05 \%$ respectively compared to $\mathrm{IC}_{50}$ of METH. Further, results showed that CAE protects $\mathrm{SH}_{-} \mathrm{SY}_{5} \mathrm{Y}$ cells from METHinduced cell death. 

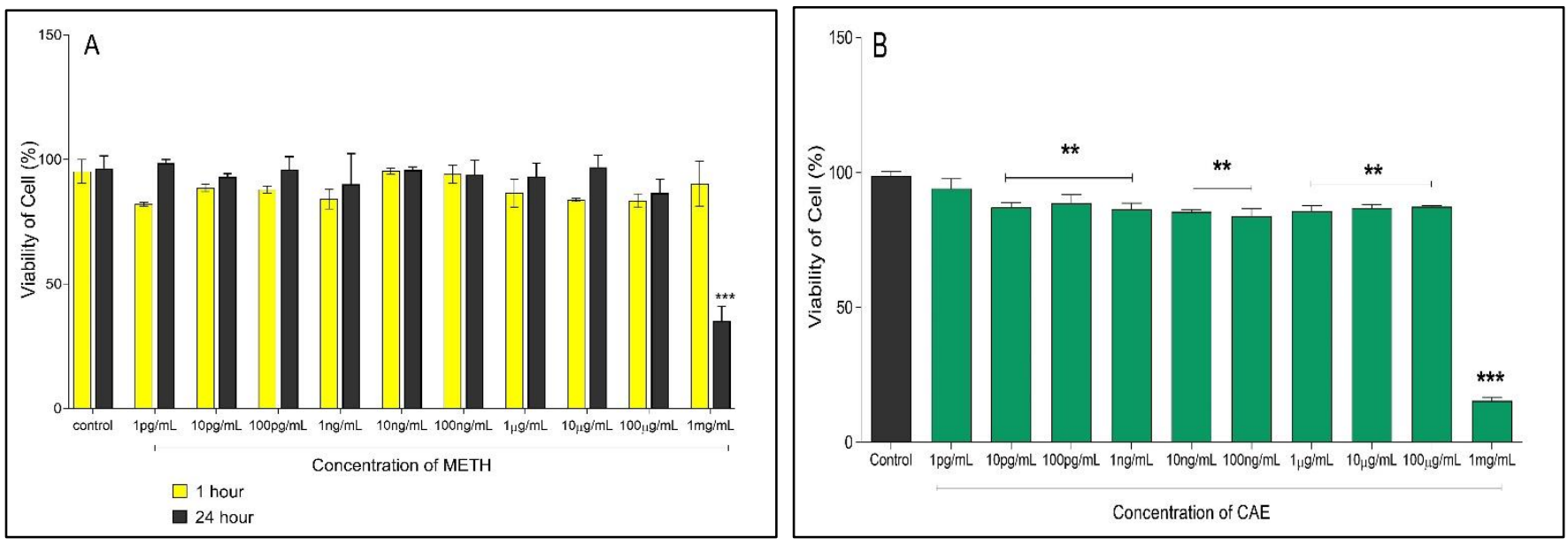

Figure 2. (A) The cytotoxicity of METH on undifferentiated SH-SY5Y following 1 and 24 hour incubation. (B) The cytotoxicity of CAE on undifferentiated $\mathrm{SH}_{-} \mathrm{SY}_{5} \mathrm{Y}$ cells following 24 hours incubation. Statistical analysis was done using one-way ANOVA followed by Tukey's multiple comparison. Control denoted as $100 \%$ cell viability. Data expressed as the mean \pm SEM. ${ }^{* * *} \mathrm{P}<0.001,{ }^{* *} \mathrm{P}<0.01,{ }^{*} \mathrm{P}<0.05$ statistically significant as compared to control.

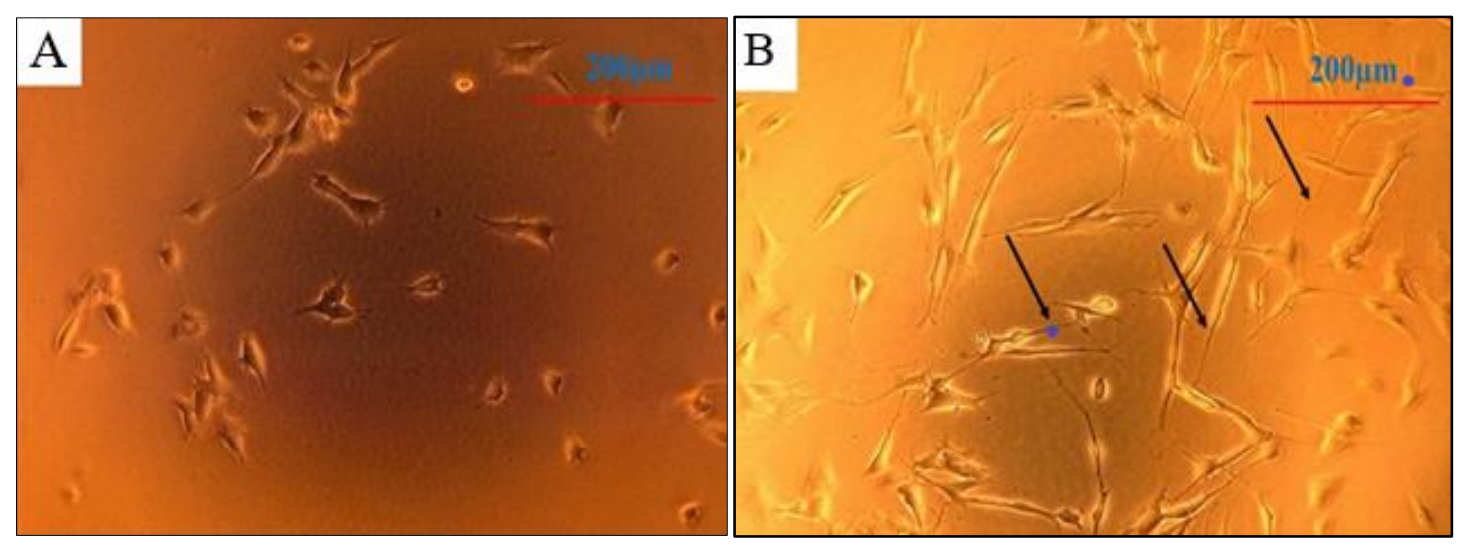

Figure 3. Morphology of undifferentiated and differentiated SH-SY5Y cells as observed under 2Ox magnification using a light-inverted microscope (Leica, Germany). (A) Undifferentiated SH-SY5Y cells with flat-phenotype. (B) After 5 days differentiation with $10 \mu \mathrm{M}$ all-trans RA, cell was transformed with elongated neurite (black arrow). 

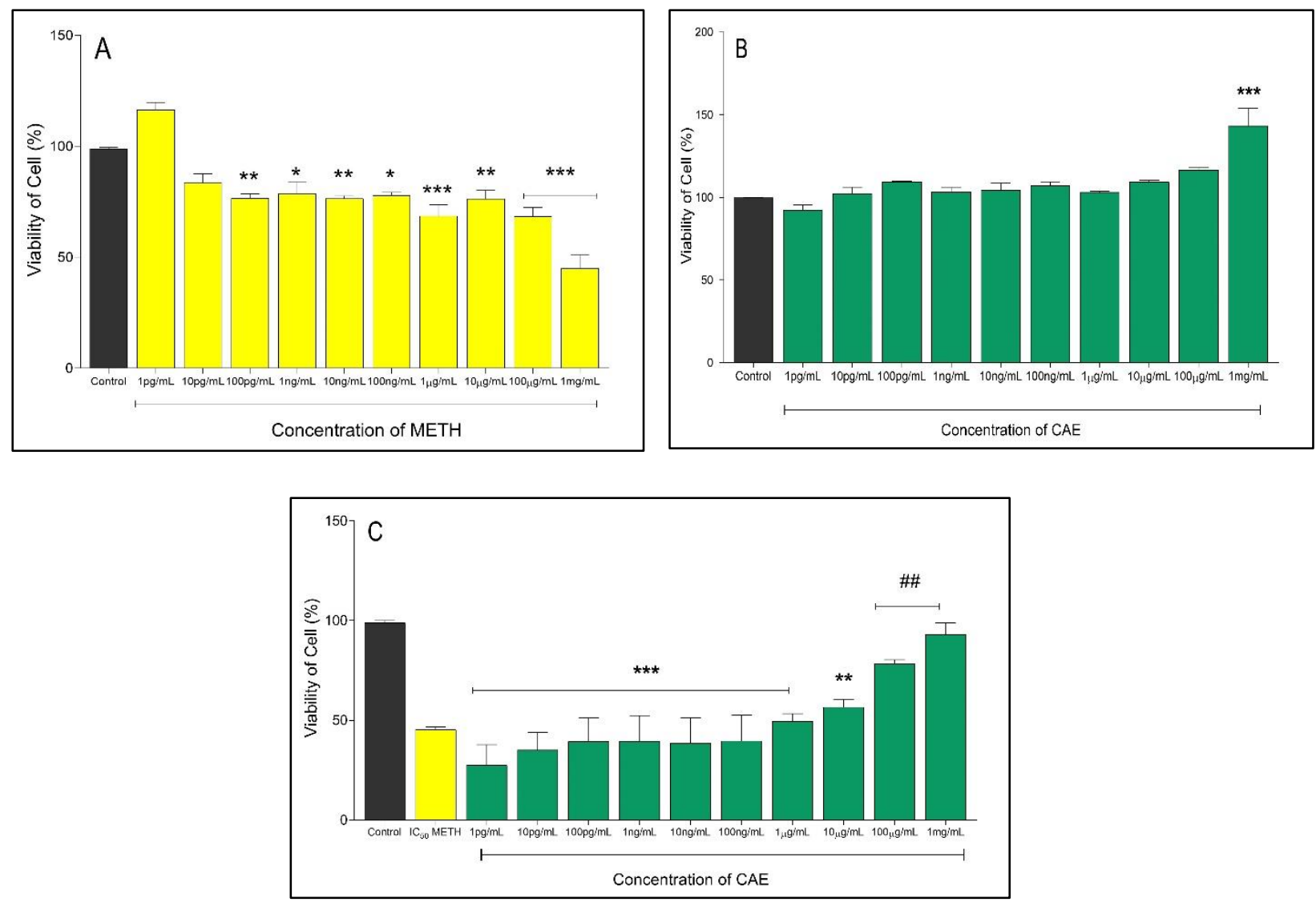

Figure 4 (A) Neurotoxicity of METH on differentiated SH-SY5Y cells following 24 hours incubation. (B) The neurotoxicity of CAE on differentiated $\mathrm{SH}_{5} \mathrm{SY}_{5} \mathrm{Y}$ cells following 24 hours incubation. (C) The effects of CAE on METH-treated differentiated SH-SY5Y cells. Cells were pre-treated with $\mathrm{IC}_{50}$ of METH $(1 \mathrm{mg} / \mathrm{mL})$ for 24 hours before post-treatment CAE for the next 24 hours. Statistical analysis was done using one-way ANOVA followed by Tukey's multiple comparison. Control denoted as 100\% cell viability. Data expressed as the mean \pm SEM. ${ }^{* *} \mathrm{P}<0.001,{ }^{* *} \mathrm{P}<0.01,{ }^{*} \mathrm{P}<0.05$ statistically significant as compared to control s. Data expressed as the mean $\pm \mathrm{SEM}$. ${ }^{* *} \mathrm{P}<0.001,{ }^{* *} \mathrm{P}<0.01,{ }^{*} \mathrm{P}<0.05$ statistically significant as compared to control while \#\#\#P<0.001, \#\# $\mathrm{P}<0.01$, \# $\mathrm{P}<0.05$ statistically significant as compared to METH $\mathrm{IC}_{50}$.

\section{DISCUSSIONS}

METH has been reported to cause neurological dysfunction and neurotoxicity in the CNS of humans and rodents model (Davidson et. al., 2001; Bowyer \& Hani, 2014). METH induces neurotoxicity through several mechanisms including mitochondrial dysfunction, oxidative stress, neuroinflammation and apoptosis (Yang et al., 2018). To date, there is interest in plant-derived medicine as an alternative to treat various neurodegenerative diseases and neuronal-cell death related to METH-induced neurotoxicity.

In this study, we attempted to elucidate the cytotoxicity, neurotoxicity and effects of CAE treatment by determining cell viability via MTS assay using in vitro $\mathrm{SH}_{-} \mathrm{SY}_{5} \mathrm{Y}$ experimental model. Firstly, we conducted a cytotoxicity assay to determine the effects of CAE and METH on undifferentiated $\mathrm{SH}_{-} \mathrm{SY}_{5} \mathrm{Y}$ cells. It is crucial to evaluate the cytotoxicity of METH and CAE at the early phase of the preclinical study to ensure its safety and efficacy prior to clinical study. Suwanjang et al. (2010) reported, METH caused a reduction in the cell viability of $\mathrm{SH}_{-} \mathrm{SY}_{5} \mathrm{Y}$ cells through dose and timedependent manners. Similarly, in this study, we have demonstrated that there was no significant change in the cell viability following short exposure ( $1 \mathrm{~h}$ incubation) of METH on the SH-SY5Y cells. Meanwhile, a significant inhibitory effect was observed at high concentration of METH $(\geq 1 \mathrm{mg} / \mathrm{mL})$ following longer $(24 \mathrm{~h})$ exposure of METH. In this study, METH doses $>1 \mathrm{mM}$ induced cell death by time and dose-dependent in agreement with Wu et al. (2007) which claimed that METH $<3 \mathrm{mM}$ caused 
apoptotic cell death in the undifferentiated $\mathrm{SH}_{-} \mathrm{SY}_{5} \mathrm{Y}$ cells. Apart from that, the vulnerability of human cancer cells towards a low dose of METH is probably due to the upregulation of pro-survival protein Bcl-2 (El-Ayadi \& Zigmond, 2011). This study shows that CAE (1mg/mL) has strong inhibitory effects on the viability of the undifferentiated SH-SY5Y cells. According to Omar et al. (2011), CAE $\geq$ $100 \mu \mathrm{g} / \mathrm{mL}$ is found to be toxic to the cells. This cytotoxicity is due to asiatic acid found in CAE which induced apoptosis and cell death (Park et al., 2005). Sakonsinsiri et al. (2018) also reported antitumor and cytotoxicity of CAE attributed by its high alkaloidal content.

Ethical concern, relatively high cost and maintenance are limitations of primary mammalian cells for toxicity and neuroscience study (Kovalevich \& Langford, 2013). Addition of a differentiation-inducing agent such as all-trans retinoic acid (RA), the $\mathrm{SH}_{-} \mathrm{SY}_{5} \mathrm{Y}$ cells were differentiated into dopaminergic neuron-like cells (Pahlman et al., 1984). Thus, transformed neuronal-like cell lines can be used to overcome these limitations. Morphological changes of the cells into long and elongated-branch neurites that connect to surrounding cells were observed in RA-differentiated cells as compared to undifferentiated cells are in line with Shipley et al. (2017). In this study, we performed both cytotoxicity and neurotoxicity assays using differentiated and differentiated $\mathrm{SH}_{-} \mathrm{SY}_{5} \mathrm{Y}$ cells in order to evaluate the vulnerability of these cells towards CAE and METH. Cecchi et al. (2008) reported that undifferentiated and differentiated $\mathrm{SH}_{-} \mathrm{SY}_{5} \mathrm{Y}$ cells display different vulnerability to toxic $\beta$-amyloid.

Generally, neurotoxicity is defined as any physical damage to neuronal cells. In this study, METH conferred a significant reduction on cell viability of the differentiated $\mathrm{SH}_{-} \mathrm{SY}_{5} \mathrm{Y}$ through a dose-dependent manner. The result proves that METH gave oxidative stress-environment to neuron-like cells. Nara et al. (2010) similarly indicates that METH $>7 \mathrm{mM}$ significantly caused neuronal cell death on the differentiated SH-SY5Y cells. According to Badisa et al. (2019), METHinduced neurotoxicity through generation of ROS. ROS causes inhibition of mitochondrial protein complexes which disturbs the normal function of mitochondria (Shin et al., 2018). This action induced mitochondrial $\mathrm{Ca}^{2+}$ dysregulation which leads to cell death (Andres et al., 2015). Interestingly, our data demonstrate a wide range of concentrations from pictogram
( $\mathrm{pg} / \mathrm{mL}$ ) to milligram $(\mathrm{mg} / \mathrm{mL})$ of METH. Thus, implying that METH at $1 \mathrm{pg} / \mathrm{mL}$ significantly possessed neurotoxicity effects on differentiated $\mathrm{SH}_{-} \mathrm{SY}_{5} \mathrm{Y}$ cells. In this study, it was observed that CAE at the highest concentration $(1 \mathrm{mg} / \mathrm{mL})$ showed highly significant maximal cell viability which are in line with Hafiz et al. (2020).

As in Figure $4 \mathrm{C}, \mathrm{CAE}$ reverses the toxicity of METH by induce the cell viability with a significant increase in cell viability at $100 \mu \mathrm{g} / \mathrm{mL}$ and $1 \mathrm{mg} / \mathrm{mL}$ as compared to $\mathrm{METH}$ $\mathrm{IC}_{50}$. This effective treatment further showed that protecting the $\mathrm{SH}_{-} \mathrm{SY}_{5} \mathrm{Y}$ cells upon oxidative stress by CAE has also been demonstrated by Omar et al. (2011) that CAE at the concentration ranging from $1 \mu \mathrm{g} / \mathrm{mL}$ to $50 \mu \mathrm{g} / \mathrm{mL}$ is capable to protect neuron cells from oxidative stress and apoptotic cell death induced by buthionine sulfoximine (BSO). Neuroprotective effects of CAE are probably due to a high content of antioxidant activities (Zainol et al., 2003). Bioactive triterpenes such as asiatic acid and medacassic acid exert protective effects against oxidative cellular damage in dopaminergic neurons in vitro. Antioxidant properties of CAE may also mediated by increases in superoxide dismutase (SOD) and catalase activity. Besides that, CAE also acts as a potent scavenger of free radicals. Hussin et al. (2007) documented that Centella asiatica able to increase endogenous antioxidant enzymes and reduce lipid peroxidation by free radicals. Bioactive constituents of CAE also may activate cell- specific signalling pathways such as activation of pro-survival and anti-apoptotic mechanism thereby attenuating neuronal-cell death. In addition, CAE and its bioactive constituents affects CNS possibly through the anti-inflammatory activity by inhibiting NF-Kb activation and the PI3K/AKT and ERK1/2 signalling pathway (Mairuae et al., 2019).

In future, further study needs to be done in order to comprehensively identify the mechanism which involves in the treatment of CAE on METH-induced neurotoxicity.

\section{CONCLUSION}

This in vitro preliminary study is suggested CAE as therapeutic natural-derived protective agent to attenuate the neuronal cell death induced by psycho-stimulant drug, METH. 


\section{ACKNOWLEDGEMENT}

This work was financially supported by the Ministry of Agriculture of Malaysia (100-RMI/MOA 16/6/2 3(2015) NKEA research grant scheme. The authors would also like to thank
Institute of Science (IOS), Atta-Ur-Rahman Research Institute for Natural Product Discovery (AuRins) and Faculty of Pharmacy, UiTM for the research facilities.

\section{REFERENCES}

Andres, MA, Cooke, M, Bellinger, FP, Berry, FP, Zaporteza, M, Rueli, RH, Barayuga, SM \& Chang, L 2015, 'Methamphetamine acutely inhibits voltage-gated calcium channels but chronically upregulates L-type channels', J Neurochem, vol. 134, no. 10, pp. 56-65.

Badisa, RB, Wiley, C, Randell, K, Darling-Reed, SF, Latinwo, LM, Agharahimi, M, Soliman, KFA \& Goodman, CB 2019, 'Identification of cytotoxic markers in methamphetamine treated rat C6 astroglia-like cells', Nature, vol. 9, pp. 1-12.

Bowyer, JF \& Hanig, JP 2014, 'Amphetamine and Methamphetamine-induced hyperthermia: Implications of the effects produced in brain vasculature and peripheral organs to forebrain neurotoxicity', Temperature, vol. 1, no. 3, pp. 172-182.

Cecchi, C, Pensalfini, A, Liguri, G, Baglioni, S, Fiorillo, C, Guadagna, S, Zampagni, M, Formigli, L, Nosi, D \& Stefani, M 2008, 'Differentiation increases the resistance of neuronal cells to amyloid toxicity, Neurochem Res, vol. 33, pp. 25162531.

Davidson, C, Gow, A.J, Lee, TH, Ellinwood, EH 2001, 'Methamphetamine neurotoxicity: Necrotic and apoptotic mechanisms relevance to human abuse and treatment', Brain Research Reviews, vol. 36, pp. 1-22.

El-Ayadi, A \& Zigmond, MJ 2011, 'Low concentrations of Methamphetamine can protect dopaminergic cells against a larger oxidative stress injury: Mechanistic study', PLos ONE, vol. 6 , no. 10, pp. 1-14

Foster, JI, Koglsberger, S, Trefois, C, Boyd, O, Baumuratov, AS, Buck, L, Bailling, R \& Antony, PMA 2016, 'Characterization

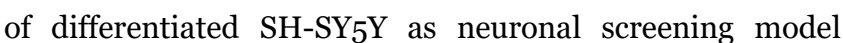
reveals increased oxidative vulnerability', Journal of Biomolecular Screening, vol. 12, no. 5, pp. 496-509.

Galbraith, N 2015, 'The methamphetamine problem commentary on Psychiatric morbidity and sociooccupational dysfunction in residents of a drug rehabilitation centre', BJPsych Bull, vol. 39, pp. 218-220.

Genc, K, Genc, S, Kizildag, S, Sonmez, U, Yilmaz, O, Tugyan, K., Ergur, B, Sonmez, A \& Buldan, Z 2003, 'Methamphetamine induces oligodendroglial cell death in vitro', Brain Research, vol. 982, no. 1, pp. 125-130.

Hafiz, ZZ, Mohd Amin, MA, Johari James, RM, The, LK, Salleh, MZ \& Adenan, MI 2020, 'Inhibitory effects of rawextract Centella asiatica (RECA) on acetylcholinerase, inflammations, and oxidative stress activities via in vitro and in vivo', Molecules, vol. 25, pp. 1-20. doi: 10.3390/molecules25040892.

Hussin, M, Abdul-Hamid, A, Mohamad, S, Saari, N, Ismail, M \& Bejo, MH 2007, 'Protective effect of Centella asiatica extract and powder on oxidative stress in rats', Food Chemistry, vol. 100, pp. 535-541.

Kovalevich, J \& Langford, D 2013, 'Considerations for the

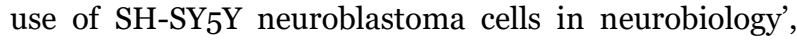
Methods Mol. Biol, vol. 1078, pp. 9-21.

Kumari, S, Deori, M, Elancheran, R, Kotoky, J \& Devi, R 2016, 'In vitro and in vivo antioxidant, antihyperlipidemic properties and chemical characterization of Centella asiatica (L.) extract', Frontiers in Pharmacology, vol. 7, no. 400, pp. 1-12.

Mairuae, N, Cheepsunthorn, P \& Buranrat, B 2019, 'Antiinflammatory and anti-oxidative effects of Centella asiatica extract in lipopolysaccharide-stimulated BV2 microglial cells', Pharmacogn. Mag, vol. 15, pp. 140-146.

McDonnell-Dowling, K \& Kelly, JP 2017, 'The role of oxidative stress in methamphetamine-induced toxicity and sources of variation in the design of animal studies', Current Neuropharmacology, vol. 15, no. 2, pp. 300-314. Nara, A, Aki, T, Funakoshi, T \& Uemura, K 2010, 'Methamphetamine induces micropinocytosis in

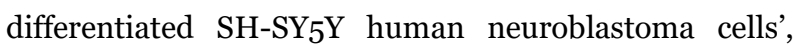
Brain Research, pp. 1352, 1-10.

Omar, NS, Che Zakaria, ZA, Mian, TS, Wan Ngah, WZ, Mazlan, M 2011, 'Centella asiatica modulates neurons cell survival by altering caspase-9 pathway', Journal of Medicinal Plants Research, vol. 5, no. 11, pp. 2201-2109.

Pahlman, S, Ruusala, AL, Abrahamson, L, Mattsson, ME \& Esscher, T 1984, 'Retinoic acid-induced differentiation of 
cultured human neuroblastoma cells. A comparison with phorbolester-induced differentiation', Cell Differ, vol. 2, pp. 135-144.

Park, BC, Bosire, KO, Lee, ES, Lee, YS \& Kim, JA 2005, 'Asiatic acid induces apoptosis in SK-MEL-2 human melanoma cells', Cancer Letters, vol. 218, pp. 81-90.

Ramanathan, M, Sivakumar, S, Anandvijayakumar, PR, Saravanabanun, C \& Rathinavel Pandian, P 2007, 'Neuroprotective evaluation of standardized extract of Centella asiatica in monosodium glutamate treated rats', Indian Journal of Exprimental Biology, vol. 45, pp. 245-431.

Ramkissoon, A \& Wells, PG 2015, 'Methamphetamine oxidative stress, neurotoxicity, and functional deficits are modulated by nuclear factor-E2-related factor 2', Free Radical Biology and Medicine, vol. 89, pp. 358-368.

Rosas-Hernandez, H, Cuevas, E, Lantz, SM, Rice, Kc, Gannon, BM, Fantegrossi, WE, Gonzalez, C, Paule, MG \& Ali, SF 2016, 'Methamphetamine, 3, 4- methylenedioxymethamphetamine (MDMA) and $\quad 3,4-$

methylenedioxypyrovalerone (MDPV) induce differential cytotoxic effects in bovine brain microvessel endothelial cells', Neuroscience Letters, vol. 629, pp. 125-130.

Sakonsinsiri, C, Kaewlert, W, Armartmuntree, N, Thanan, R \& Pakdeechote, P 2018, 'Anti-cancer activity of asiatic acid against human cholangiocarcinomacells through inhibition of proliferation and induction of apoptosis', Cell Mol Biol, vol. 64, no.10, pp. 28-33.

Shen, X, Guo, M, Yu, H, Liu, D, Lu, Z \& Lu, Y 2019, 'Propionibacterium acnes related anti-inflammation and skin hydration activities of madecassoside, a pentacyclic triterpene saponin from Centella asiatica', Bioscience, Biotechnology, and Biochemistry, vol. 83, no. 3, pp. 561-568.

Shin, EJ, Tran, HQ, Nguyen, PT, Jeong, JH, Nah, SY, Jang, CG, Nabeshima, T \& Kim, HC 2018, 'Role of mitochondria in methamphetamine-induced dopaminergic neurotoxicity: involvement in oxidative stress, neuroinflammation and proapoptosis- a review', Neurochemical Research, vol. 43, no. 1, pp. 66-78.

Shipley, MM, Mangold, CA \& Szapara, ML 2017, 'Differentiation of the $\mathrm{SH}_{-} \mathrm{SY}_{5} \mathrm{Y}$ human neuroblastoma cell line', J.Vis. Exp, vol. 108 (53193), pp. 1-19. doi: 10.3791/53193. Sripanidkulchai, K, Techataweewan, N, Tumsan, Y, Pannanggrong, W \& Sripnaidkulchai, B 2007, 'Prevention of indomethacin induced gastric ulcers in rats by extract from leaves of Centella asiatica', Siriraj Med J, vol. 59, no.3, pp. $1150-1154$.

Suwanjang, W, Phansuwan-Pujito, P, Govitsang, P \&
Chetsawang, B 2010, 'The protective effect of melatonin on methamphetamine-induced calpain-dependent death pathway in human neuroblastoma $\mathrm{SH}-\mathrm{SY}_{5} \mathrm{Y}$ cultured cells', Journal of Pineal Research, vol. 48, no. 2, pp. 94101.

Ternchoocheep, K, Surangkul, D \& Ysothonsreekul, S 2017, 'The recovery and protective effects of asiatic acid on

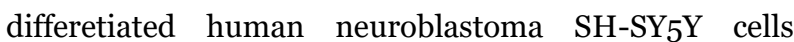
cytotoxic-induced by cholesterol', Asian Pacific Journal of Tropical Biomedicine, vol. 7, no. 5, pp. 416-421.

Veerandra Kumar, MH \& Gupta, YK 2002, 'Effect of different extracts of Centella asiatica on cognition and markers of oxidative stress in rats', J Ethnopharmacol, vol, 79, no. 2, pp. 253-26o.

Wang, P, Long, TF, Wang, LP \& Song, J 2019, 'Synergistic effect of asiatic acid and madecassic acid against antioxidant deficit in rat peripheral nervous system', International Journal of Pharmacology, vol. 15, no. 7, pp. 837-843.

Wu, CW, Pin, YH, Yen, JC, Chang, CY, Wan, SF, Yeh, CL, Chi, CW \& Lee, HC 2007, 'Enhanced oxidative stress and aberrant mitochondrial biogenesis in human neuroblastoma $\mathrm{SH}_{-} \mathrm{SY}_{5} \mathrm{Y}$ cells during methamphetamine induced apoptosis', Toxicology and Applied Pharmacology, vol. 220, pp. 243-251.

$\mathrm{Xu}, \mathrm{CL}$, Wang, QZ, Sun, LM, Li, XM, Deng, JM, Li, LF, Zhang, J, Xu, R \& Ma, SP 2012, 'Asiaticoside: Attenuation of neurotoxicity induced by MPTP in rat model of Parkinsonism via maintaining redox balance and upregulating the ration of Bcl-Bax', Pharmacology, Biochemistry and Behaviour, vol. 100, pp. 413-418.

Xu, M, Xiong, Y, Liu, J, Qian, J, Zhu, L \& Gao, J 2012, 'Asiatic acid, a pentacyclic triterpene in Centella asiatica, attenuates glutamate-induced cognitive deficits in mice

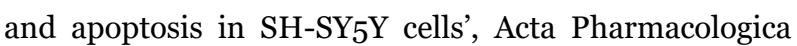
Sinica, vol. 33, no. 5, pp. 578-587.

Yang, X, Wang, Y, Li, Q, Zhong, Y, Chen, L, Du, Y, He, J, Liao, L, Xiong, K, Yi, CX \& Yan, J 2018, 'The main molecular mechanisms underlying methamphetamineinduced neurotoxicity and implications for pharmacological treatment', Frontiers in Molecular Neuroscience, vol. 11, no. 186, pp. 1-18. doi: 10.3389/fnmol.2018.00186.

Zainol, MK, Abd-Hamid, A, Yusof, S \& Muse, R 2003, 'Antioxidative activity and total phenolic compound of leaf, root and petiole of four accessions of Centella asiatica (L.) Urban', Food Chemistry, vol. 2, pp. 575-581. 